\title{
Who Was Swimming Naked When the Tide Went Out? Introducing Criminology to the Finance Curriculum
}

\author{
Jacqueline M. Drew and Michael E. Drew
}

Griffith University, Australia

\begin{abstract}
Finance programs around the world have been revising their curricula following the Global Financial Crisis (GFC). While much of the debate has centred on the dominance of scientific and quantitative pedagogical approaches to finance education in business schools, one of the most egregious aspects uncovered during the deleveraging of the financial system was the scale and scope of finance crime and financial fraud (including the Madoff scandal, described as the largest Ponzi scheme in history). This paper argues that those "on the inside", the professionals within the finance industry, have a central role to play in safeguarding the ethics and integrity of financial markets. It is our conjecture that prevention and earlier detection of finance crime and financial fraud may be addressed, in part, by better educating finance professionals about these issues. We posit that the enormity of illegal activity uncovered in the wake of the GFC demands, as a matter of priority, the integration of criminological and criminal justice theory into the finance curriculum.
\end{abstract}

Keywords: finance curriculum, criminology and criminal justice across the curriculum, financial crime and fraud, pedagogy.

\section{Introduction}

Mr Warren Buffett famously stated, "after all, you only find out who is swimming naked when the tide goes out" (Chairman's Letter Berkshire Hathaway 2002). This quote has been cited often following the Global Financial Crisis (GFC) as it eloquently captures the liquidity crisis that engulfed the global economy. The deteriorating economic outlook, heightened systemic risk, the collapse of financial markets and an erosion of confidence sparked a run on fund withdrawals, as institutional and individual investors moved swiftly to liquefy their holdings (Benson 2009, Drew and Drew 2010). Given the radical fall in liquidity, the GFC was a primary catalyst in the exposition of the single largest episode of finance crime and financial fraud in generations.

The dislocation of economies and markets during the GFC, in concert with the egregious nature of the finance crime and fraud committed, has seen significant and important questions raised about the role and impact of business education. Emotive arguments have been proffered concluding that middle and senior finance professionals are products of business schools. In turn, it has been concluded that business schools are largely to blame for the unethical behaviour, 
manifested as unabashed self-interest, profit-maximisation and greed, uncovered post-GFC (Giacalone and Wargo 2009). In the wake of the financial crisis, popular media have questioned those who have "created" these business leaders:

"Business schools: a failing grade on ethics" (Gentile 2009)

"Who taught them greed is good? To what extent are business schools' MBA courses responsible for the global financial crash?" (Walker 2009)

Interest in business ethics inevitably ebbs and flows as events in the financial marketplace draw attention to its flaws. Similar reflection took place following the dot.com crash and accounting scandals occurring in the beginning of the previous decade (namely, Enron and WorldCom) (Friedrichs 2010, Giacalone and Wargo 2009). So with the advent of the GFC, practitioners and academics alike have again taken a renewed focus on the ethical conduct of business leaders. The enormity of the events, involving well-known and respected investment houses, the high profile individuals involved and magnitude of financial losses across a wide spectrum of the consumer population has put business education and specifically, ethics, under the microscope (Balotsky and Steingard 2006).

A review of the academic literature that has addressed business ethics indicates that recent discussions are generally placed against the backdrop of a body of research that stretches back more than 25 years (Balotsky and Steingard 2006). To date, this body of work has produced promising findings. Most would conclude that ethics education is valuable and can make a difference, however a clear and consistent answer to how business schools most successfully impact on business ethics remains open (Balotsky and Steingard 2006). How ethics should be taught, the content of business ethics courses and what outcomes can be achieved are topics that continue to be examined (Nguyen, Basuray, Smith, Kopka, and McCulloh 2008). The paper builds on this previous body of work, contributing to the debate through an examination of the financial crime and fraud identified by the GFC and prosecutes the case for formal inclusion of criminological and criminal justice content within the finance curriculum.

As stated earlier, the liquidity crunch associated with the GFC was instrumental in exposing significant criminal and fraudulent practices in global financial markets. This paper considers the role and emphasis given to finance crime and in particular, the prevention and detection of financial fraud in finance curricula. It is proposed that a positive outcome that could be drawn from the scandals uncovered by the GFC is a recognition that the finance curriculum should and must draw on the work of criminologists and criminal justice scholars to enhance the robustness of the program. The paper argues that the role of "insiders", those that work within the finance industry as finance professionals, are central to the ethical conduct and professional practice within the financial markets. We need to take significant and meaningful steps towards better educating these "finance insiders". The next generation of graduates must grasp 
the prevalence of financial crime and fraud and the devastating impact it can have on the confidence of consumers and, ultimately, the integrity of the global financial system.

\section{Finance Crime and Financial Fraud Uncovered Post-GFC}

In order to provide a view on what criminology and criminal justice content is required within the finance curriculum it is essential to consider the type of finance crime and financial fraud that was uncovered in the wake of the GFC. This analysis is instructive as it provides a basis on which to determine the specific criminological content that would be most useful in ensuring that finance professionals are an essential resource in the prevention, detection and reporting of illegal activities within markets.

2.1. The Financial Boom, Growing Numbers of Participators and Complex Financial Products and Services

It has been argued that the enormity of financial frauds that were uncovered following the GFC were able to be perpetrated more easily as they were camouflaged by the euphoria of the market during the financial boom (Tomasic 2011). Recent reports of the key enforcement actions taken by the US Securities and Exchange Commission (SEC) (through to August 2011) provide some indication of the types of misconduct which led or arose from the financial crisis (SEC 2011). The SEC has taken action against numerous entities that were found to have, "... concealed from investors risk, terms, and improper pricing in collateralised debt obligations (CDOs) and other complex structured products, made misleading disclosures to investors about mortgage-related risks and exposure and concealed the extent of risky mortgage-related and other investments in mutual funds and other financial products" (SEC 2011).

Further, Hudson and Maioli (2010) concluded that a major contributor to the crisis was the burgeoning complexity of both products and participators in the financial system. The financial system expanded to include a large number of new and complex financial products, most notably derivatives that required sophisticated and advanced knowledge of risk management and financial engineering. A raft of new players also entered the market, such as those in shadow banking activities (including hedge funds, a segment we will return to later in the paper), structured investment vehicles (SIVs) and private equity funds. It is alleged that the misconduct was able to be enacted given that regulation and transparency of these market participators was relatively weak (Hudson and Maioli 2010). 
In late 2009, the US Department of Justice announced the establishment of the interagency Financial Fraud Enforcement Taskforce. Attorney General Eric Holder stated that “... this task force's mission is not just to hold accountable those who helped bring about the last financial meltdown, but to prevent another meltdown from happening" (US Dept. of Justice 2009). The Financial Fraud Enforcement Taskforce by the end of 2010 reported that Operation Broken Trust which involved a massive investment fraud sweep across the United States (between 16 August and 1 December 2010), resulted in the identification of 211 cases of investment fraud involving over 120,000 victims and more than US\$8 billion (Federal Bureau of Investigation (FBI), 2010). Whilst the majority of cases were Ponzi schemes, other frauds identified included market manipulation ("pump and dump"), affinity fraud, real estate investment fraud, commodities fraud, business opportunity fraud and foreign exchange fraud (FBI 2010). From the beginning of 2009 through to the end of 2010, over 200 Ponzi scheme cases were opened, involving more than US\$20 million (FBI 2010).

Classification of cases of misconduct (such as those highlighted) as instances of finance crime and financial fraud provide a useful foundation on which to argue for the integration of criminology into the finance curriculum. Finance crime captures activities of "large-scale illegality that occurs in the world of finance and financial institutions" (Friedrichs 2010, p. 168). Financial fraud is used to refer to entities or individuals that "carry out a swindle while appearing to be engaged in a legitimate enterprise" (Friedrichs 2010, p. 200). We consider each of these issues in the following sections.

\subsection{Finance Crime}

Finance crime can take a myriad of forms and, as history has taught us all too frequently, is dynamic in its scope, nature and modus operandi. In recent years, the burgeoning shadow banking sector, in particular the rise of hedge funds, has illustrated the different ways unethical practice can adversely impact investors in these funds and materially heighten systemic risk. To provide some context, the global hedge fund industry now stands at around US\$2 trillion and, while a relatively small part of the global financial markets, is a key element of the shadow banking system (Hedge Fund Research (HFR) cited by Herbst-Bayliss 2011). Unethical practice in the hedge fund arena can include: misrepresentation (for example, misreporting the performance of a hedge fund); and, omission (investment risk - exposure to, say, subprime mortgages; liquidity risk - the level of redemption requests; and, operational risks - people, technology, proprietary models and data/information); and, most audaciously, fabrication (Bollen and Pool 2009).

In an effort to identify fraudulent activity before massive losses are incurred, institutional investors perform due diligence and regulators examine hedge funds, 
often after receiving complaints from investors (Bollen and Pool 2009, 2010). The due diligence challenge facing investors globally relating to the risks of misrepresentation, omission and fabrication in hedge funds cannot be underestimated. Recent research by Brown, Goetzmann, Liang and Schwarz (2012) found that one in five hedge fund managers misrepresents their fund or its performance to investors during formal due diligence investigations. Using confidential data taken from 444 due diligence reports commissioned by investors between 2003 and 2008, Brown et al. (2012) analysed the extent to which hedge fund managers' representations about their funds differed from reality. Managers most frequently misrepresented the size of funds under management in the hedge fund, the performance (or track record) of the fund and their regulatory and legal histories (Brown et al. 2012). The research also identified "noted verification problems"-characterised as "misrepresentations or inconsistencies"- in 42 per cent of due diligence reports (Brown et al. 2012).

The severity of these findings from the hedge fund sector underscores the myriad of risks facing investors. It also highlights that while the Madoff and Bayou scandals focus debate on issues of fabrication (discussed below), the frequent occurrence of misrepresentation and omission in financial transactions demands that such risks are identified and actively mitigated.

\subsection{Financial Fraud}

Francis (1988) used the term "contrepreneurs" (derived from "con artist" and "entrepreneur") to describe individuals who "carry out a swindle while appearing to be engaged in a legitimate enterprise" (Friedrichs 2010, p. 200). Fraud, and of particular relevance to this discussion, financial fraud is a contrepreneurial crime. The most obvious example of a contrepreneurial crime uncovered in the wake of the GFC was the Madoff Ponzi scheme. Madoff's scheme is used as but one illustrative example of the fabrication-type of financial fraud that were subsequently uncovered following the GFC.

Bernard Madoff operated a Ponzi scheme estimated to be worth US\$65 billion (Benson 2009, Tomasic 2011). Madoff operated what was perhaps the largest and longest Ponzi scheme in history (Drew and Drew 2010), operating across more than 2 decades (Tomasic 2011) and withstanding sixteen years of SEC investigation (Office of Investigations (SEC) 2009). The perpetration of Ponzi schemes involves raising money from investors who believe they are investing in a legitimate investment or business strategy usually with the promise of high and sustained investment returns (Drew and Drew 2010). Unbeknown to investors there is no legitimate investment strategy being followed and any returns or annuities gained by investors are being funded by new investors contributing to the scheme (Drew and Drew 2010). Madoff's Ponzi scheme finally came "unstuck" during the GFC when the liquidity demands of investors 
exceeded the ability of the scheme to attract new investors (Drew and Drew 2010).

Serious questions have been asked about how Madoff could have perpetrated his crime for so long and remain undetected (Drew and Drew 2010). It is well documented that Harry Markopolos made numerous complaints to the SEC regarding his suspicions that Madoff was running a Ponzi scheme (Office of Investigations (SEC) 2009). Madoff was able to avoid detection by advantageously using his reputation developed from his legitimate business practice, such as his former position as the President of the Board of Directors for the NASDAQ and evade scrutiny by demanding investors "not ask too many questions" about his investment technique (Benson 2009, Tomasic 2011).

This case demonstrates the classic elements and operandi of white collar crime. White collar crimes typically appear legitimate, the victim and offender are spatially separated and the offender has legitimate access to the place in which the crime occurs (Benson and Simpson 2009). White collar criminals effectively abuse trust, conceal their activities and engage in deceptive conduct (Benson and Simpson 2009).

\subsection{The Way Forward}

The scope and breadth of misconduct issues uncovered in the years following the financial crisis have been both surprising and shocking. The question posed by Michel (2008) is poignant and central to the issues under consideration in this paper. Specifically Michel (2008) asks, “... are we powerless before these deceitful individuals?" (p. 383). Based on the discussion presented here, should we simply accept that it is inevitable that finance crime and financial fraud will flow unchecked during times of financial boom and significant growth of financial services, products and market participants? Surely, we must answer in the negative. Illegal activities within our financial system will always occur; just as street crime will never be eradicated, however there are real and significant steps that can be taken to reduce the likelihood and length of the perpetration of such crimes. While not a complete answer, the education of finance professionals is one way to ensure that those "on the inside" have the knowledge, tools and resources necessary to put up a fight (Michel 2008).

\section{The State-of-Play: Finance Curriculum and Investment/Financial Market Risk}

The definition of risk in the field of finance continues to be one of the most hotly contested ideas in the discipline. Holton (2004) neatly summarises that "... a search of the financial literature yields many discussions of risk but few 
definitions. To understand risk we must explore two streams flowing through the $20^{\text {th }}$ century. One is subjective probability. The other is operationalism. Where they meet, we can understand risk" (p. 19). One of the architects of modern finance and Nobel prize winner, Harry Markowitz (1952) offers no definition of risk in his much celebrated Journal of Finance paper, simply proposing the following rule, "... that the investor does (or should) consider expected return a desirable thing and variance of return an undesirable thing" (p. 77). This notion of risk based on the premise of deviations from what one expects (or subjective probability), is a foundation stone for much of finance curricula today. Finance academics and practitioners commonly use utility (or state preferences) to operationally define perceived risk exposure (by way of example, setting a market risk limit, portfolio optimisation, trader performance-based compensation and capital allocation) and its potential impact on financial activity (Holton 2004). However, while finance curricula explore content around the subjective probability of risk (and the associated tenets of Modern Portfolio Theory, the Capital Asset Pricing Model, the Efficient Market Hypothesis and option pricing as the received pedagogy), it is our conjecture that the next generation of finance graduates require equal fluency with concepts such as the crime triangle, white collar crime and red flag approaches to fraud identification.

\section{The Adoption and Integration of White Collar Criminology into the Finance Curriculum}

The previous discussion briefly outlined what is typically taught about risk within the finance curriculum and noted that significant emphasis is placed on training finance professionals about risk through the prism of subjective probability. What is also clear is that less consideration (if any) is given to the sizeable risks associated with fraud and the opportunity for finance crime. It should be acknowledged that fraud is addressed within the accounting curriculum (most often in courses on auditing) however it is not enough to confine these issues to accounting majors as financial crime and fraud have far-reaching implications that extend across all areas of business curriculum (Elson, O'Callaghan, Alleyne, Bernal, and Walker 2007) and in particular, finance.

Ramamoorti (2008) forwards that, given the enormity of fraud losses that have been experienced in preceding decades, that law, business and criminology schools must commit to teaching and researching the areas of fraud and forensic accounting. Our argument is that whilst other schools may teach about financial crime and fraud, it is the responsibility of business schools and in particular, the finance discipline, to ensure that this type of content is integrated into their curriculum. This approach is reinforced by the contention that business schools produce graduates with finance majors who work in industry and, given their 
position and training in financial products and instruments, are in a prime position to detect and prevent fraud.

The most recent report to the nation on occupational fraud and abuse released by the Association of Certified Fraud Examiners (ACFE) (2010) concluded that organisations rely too heavily on audits and should not be used as the only method of fraud detection. Consistent with the reference to the inclusion of fraud within the accounting curriculum, responsibility for the prevention and detection of fraud within organisations is often left to external auditors (Hillison and Pacini 1997). Responsibility must however be diversified and include others, such as the Chief Financial Officer (CFO), internal auditor and financial managers (Hillison and Pacini 1997). The ACFE concluded that the best fraud detection method is in fact employees and those organisations that invest in anti-fraud training have diminished fraud losses (ACFE 2010).

Why is it "insiders" are in the best position to identify financial crimes and fraud? In the particular case of identifying financial fraud, an individual must have a clear understanding of how regular transactions or financial processes or systems should occur in order to be able to identify anomalies and be sensitive to potential indicators of fraud (Michel 2008). It must be remembered that financial frauds are often perpetrated by highly skilled business people who seize an opportunity to engage in a fraudulent act using their sophisticated knowledge and expertise in financial products and transactions (Michel 2008). Therefore, in order to identify financial fraud individuals need to have equally sophisticated knowledge and skills across the range of complex financial products and services in the financial marketplace. Those graduating from our business schools have this body of knowledge and are in one of the best positions to detect early warning signs or "red flags" of financial crime and fraud. The ACFE (2010) research has found that those engaged in fraudulent acts can be recognised through red flags, or behavioural warning signs and as such, individuals need to be trained to recognise and identify these fraud warning signs in order to minimise fraud perpetration. Currently, this is not being done well. Based on the 2010 annual fraud survey conducted by KPMG for the purpose of assessing fraud across Australian and New Zealand organisations, it was found that red flags were ignored or overlooked in 38 per cent of major frauds (KPMG 2010). The ACFE (2010) found that, on average, fraud occurs across an 18 month period before detection.

\subsection{What Would the Curriculum Look Like?}

Given the argument that finance majors graduating from business schools are one of the most useful resources in the prevention and detection of financial crime and fraud, the following discussion centres on the type of criminological and criminal justice content that would be relevant for inclusion in the finance curriculum. 
In order to fully understand financial crimes and fraud we require an understanding of the human factors involved in the perpetration of fraud, what motivates individuals to engage in financial crime and fraud and how these crimes are committed and why (Ramamoorti 2008). Classic criminological theory posits that crime occurs as a result of the interaction in time and place of a motivated offender and a suitable target, in the absence of a capable guardian (Cohen and Felson 1979). Fraudsters are more likely to engage in fraudulent conduct when they are motivated, perceive an opportunity and guardianship is lacking (Levi and Smith 2011). According to rational choice theory, white collar criminals who are motivated and perceive an opportunity weigh up the costs and benefits of committing an illegal act, in part by accessing the strength of guardianship, making an assessment of the severity and certainty of consequential formal and informal sanctions (Benson and Simpson 2009). The original fraud triangle based on the seminal work of Sutherland (1949) and subsequently developed by Cressey (1973), echoes the tenets of opportunity and motivation (or perceived need/pressure). The fraud triangle also introduces the psychological component of fraud, rationalisation. It is proposed that fraudsters need to justify or rationalise their behaviour to themselves and others (Ramamoorti 2008). In the case of the circumstances leading up to the GFC, it is argued here that financial bubbles create a mentality that lessens reluctance to engage in unethical behaviour (Giacalone and Wargo 2009). A perfect rationalisation, in the eyes of those engaging in fraudulent behaviour, is "everyone is getting away with it" (Giacalone and Wargo 2009, p. 155).

At a minimum, teaching the basics of white collar crime, financial crime and financial fraud would involve teaching the foundational tenets of relevant criminological theories as applied to this context including psychological, rational choice, routine activities, social control, social process and conflict theories (Friedrichs 2010). In sum, specific topics are likely to include:

- Key theories and classifications of white collar crime.

- The psychology of financial crime and fraud (human factors, motivation and rationalisation).

- The nature of financial crime and fraud (opportunities and techniques).

- Assessing the cost of financial crime and fraud.

- Transactional, procedural elements of finance crime and financial fraud.

- Prevention and detection strategies as applied to financial crime and fraud. 
- Regulatory responses and legal remedies.

It is proposed that these topics would be core elements of an undergraduate finance curriculum. A theme that has been evidenced throughout the paper is the dynamic nature of finance crime and fraud. We envisage that postgraduate level course material would build on the central tenets of white collar crime considered at the undergraduate level. It would explore these concepts through discussions and group work based on criminological case study material (for instance, fraud vulnerabilities identified in CDOs/SIVs; finance crime in credit default swaps; the red flags of Ponzi schemes and feeder funds; and, the misrepresentation, omission and fabrication risk of exotic hedge fund strategies to name but a few potential advanced topics for consideration). The use of discussion- and/or group-based case studies somewhat addresses a major criticism often levelled at ethics education which questions the effectiveness of ethics education in influencing actual ethical behaviour of students once they enter the workforce (Mayhew and Murphy 2009). To further enhance the transfer of learning to actual practice it also suggested that the curriculum delivery actively incorporate practitioners as guest lecturers on topics of finance and white collar crime (Mayhew and Murphy 2009). The involvement of practitioners has a two-fold benefit of assisting students to better integrate learning into ethical action through exposure to and consideration of "real life" actual examples of corporate crime and providing the opportunity for academic staff to work more proactively in designing impactful curriculum and gauging its influence through practitioner feedback.

\subsection{The Need for a Criminologist on Faculty}

A further issue which must be addressed here, draws on a debate in the wider business ethics education literature, around whether business ethics are taught as a stand-alone course, diffused across business courses throughout the program or both (Norman 2004). Many scholars (such as Jacobs 2004, McManus Warnell 2010, Swanson and Frederick 2005) have supported the across-curriculum approach to ethics education. Dean, Beggs, and Fornaciari (2007) reflects on the Association to Advance Collegiate Schools of Business International (AACSB) approach to teaching business ethics which endorses teaching ethics across the curricula, as such ethics topics are taught within functional areas, such as finance. It is proposed that criminology and criminal justice content would be best delivered via a foundational, introductory course and then followed by integration across the finance curriculum. Therefore, students would be exposed to the way in which financial crime and fraud can be perpetrated across the financial products, services and instruments about which they are learning. It is also important that students can use the received quantitative approach to not only define risk from the subjective probability perspective, but also apply these 
techniques for the purpose of identifying the red flags of financial crime and fraud.

For example, from the pedagogical perspective, the student would engage with finance theory regarding, say, the pricing of credit default swaps, in order to conceptualise and price the instrument. Furthermore, based on their criminology training, the student would explore the fraud vulnerabilities within credit default swaps (such as tailoring, the role of rating agencies and potential counterparty risks). It is argued that this coordinated approach would place financial crime and fraud firmly on the radar of finance graduates encouraging them to take a more holistic approach to the identification and mitigation of risk.

It is important to note that the key barrier to the integration of criminology and criminal justice content across the curriculum is the same as using this approach with business ethics more generally. Such a move necessitates a level of faculty competence in ethics education and training (Dean et al. 2007, Hartman and Hartman 2004). In the case being argued here, it would require expertise in financial crime and fraud. An interesting approach to addressing this issue within business ethics education was proposed by Norman (2004). Norman (2004) identified a need for an ethicist to be included as a full member of the business faculty. The approach to teaching would be interdisciplinary, team teaching (Norman 2004). The ethicist would work with other faculty to integrate ethics into the core by stand-alone courses and contributing to classes focused on specific topic such as management, finance or marketing (Norman 2004). An advantage of this approach involving multi-disciplinary team teaching is that it contributes to ongoing continuing professional education for faculty members who learnt about ethics and vice versa (Norman 2004). It appears apparent that a similar case could be made for the inclusion of a criminologist on the finance faculty within business schools.

\section{Conclusions}

The egregious nature of finance crime and fraud identified during the GFC has been nothing short of breathtaking. While perhaps it is a dubious accolade, we posit that the GFC has been the single greatest catalyst that has led to the identification of financial crime and fraud identification in generations. One of the learnings from this extraordinary period of economic, financial, and, at times, social dislocation has been the realisation that the people who are in the best position to identify, prevent and detect financial crime are within financial institutions. It is these "insiders" that have a central role to play in upholding the ethical conduct and integrity of global financial markets and it is our responsibility as the guardians of finance curricula to ensure we exercise judicious changes to our pedagogical approach. 
The time for debate must be drawn to a close. The damage caused to the global financial architecture requires that practical, meaningful and actionable steps are taken now to revise finance curricula to enhance professional practice. The fiduciary nature of the financial markets and the consumers it serves demand nothing less. We acknowledge that education alone will never be able to "fix" unethical behaviour. In fact, future research should seek to extend our understanding of the linkages between what we teach in the classroom and actual behavioural outcomes of ethical behaviour. However, it is our conjecture that the need to better train the next generation of "insiders" provides the necessary rationale to take the next great pedagogical strides in the design and execution of finance curricula. At the risk of paraphrasing Mr. Buffett, the tide did indeed go out during the GFC, exposing an underbelly of financial crime and fraud. It is now beholden on all stakeholders in the finance industry (of which business schools are one) to provide criminological and criminal justice training to the next generation of finance graduates. 


\section{References:}

Association of Certified Fraud Examiners (2010), "Report to the Nations on Occupational Fraud and Abuse", Available at: http://www.acfe.com/rttn.aspx

Balotsky, E. R. and Steingard, D. S. (2006), "How Teaching Business Ethics Makes a Difference: Findings from an Ethical Learning Model", Journal of Business Ethics Education, 3: pp. 5-34.

Benson, S. (2009), "Recognizing the Red Flags of a Ponzi Scheme", The CPA Journal, 79(6): pp. 19-25.

Benson, M. L. and Simpson, S. S. (2009), White-Collar Crime: An Opportunity Perspective, New York: Routledge.

Bollen, N. P. and Pool, V. K. (2009), "Do Hedge Fund Managers Misreport Returns? Evidence from the Pooled Distribution", Journal of Finance, 64: pp. 2257-2288.

Bollen, N. P. and Pool, V. K. (2010), Predicting Hedge Fund Fraud with Performance Flags", Working Paper, March 12. Available at: http://papers.ssrn.com/sol3/papers.cfm?abstract_id= 1569626

Brown, S. J., Goetzmann, W., Liang, B., and Schwarz, C. (forthcoming, 2012), "Trust and Delegation", Journal of Financial Economics. Available at: http://papers.ssrn.com/sol3/ papers.cfm?abstract id $=1456414$

Buffett, W. E. (2002), “Chairman's Letter, Berkshire Hathaway Inc”, (28 Feb). Available at: http:/ /www.berkshirehathaway.com/2001ar/2001letter.html

Cohen, L. and Felson, M. (1979), "Social Change and Crime Rate Trends: A Routine Activity Approach, American Sociological Review, 44: pp. 588-608.

Cressey, D. (1973), Other People's Money, Montclair: Patterson Smith.

Dean, K. L., Beggs, J. M., and Fornaciari, C. J. (2007), "Teaching Ethics and Accreditation: Faculty Competence, Methods and Assessment", Journal of Business Ethics Education, 4: pp. 5-26.

Drew, J. M. and Drew, M. E. (2010), "The Identification of Ponzi Schemes: Can a Picture Tell a Thousand Frauds?", The Griffith Law Review, 19(1): pp. 51-70.

Elson, R. J., O’Callaghan, S., Alleyne, B. J., Bernal, S., and Walker, J. P. (2007), “An Innovative Approach for Integrating the Sarbanes Oxley Act into the Undergraduate Curriculum", Academy of Educational Leadership Journal, 11(3): pp. 59-66.

Federal Bureau of Intelligence (FBI) (2010), "Operation Broken Trust Historic Investment Fraud Sweep”, FBI News Stories (December 6). Available at: http://www.fbi.gov/news/stories/2010/ december/fraud 120610/fraud 120610

Friedrichs, D. O. (2010), Trusted Criminals: White Collar Crime in Contemporary Society $\left(4^{\text {th }}\right.$ ed.)", Belmont, CA: Wadsworth Cengage Learning.

Gentile, M. (2009), "Business Schools: A Failing Grade on Ethics", Bloomberg Newsweek (February 5). Available at: http://www.businessweek.com/bschools/content/feb2009/ bs2009025 129477 page 2.htm

Giacalone, R. A. and Wargo, D. T. (2009), "The Roots of the Global Financial Crisis Are in Our Business Schools", Journal of Business Ethics Education, 6: pp. 147-168.

Hartman, L. P. and Hartman, E. M. (2004), "How to Teach Ethics: Assumptions and Arguments", Journal of Business Ethics Education, 1(2): pp. 165-212.

Herbst-Bayliss, S. (2011), "Hedge Fund Industry Assets Swell to 1.92 Trillion", Reuters (January 19). Available at: http://www.reuters.com/article/2011/01/19/us-hedgefunds-assetsidUSTRE70I6JY20110119

Hillison, W. A. and Pacini, C. (1997), “A Guide for CFO's for Dealing with Fraud”, Journal of Corporate Accounting \& Finance, 9: pp. 45-56.

Holton, G. A. (2004). "Defining Risk". Financial Analysts Journal, 60(6): pp. 19-25.

Hudson, R. and Maioli, S. (2010), "A Response to 'Reflections on a Global Financial Crisis", Critical Perspectives on International Business, 6(1): pp. 53-71.

Jacobs, D. C. (2004), "A Pragmatist Approach to Integrity in Business Ethics", Journal of Management Inquiry, 13(3): pp. 215-223.

KPMG (2010), Forensic Fraud and Misconduct Survey 2010: Australia and New Zealand". Available at: http://www.kpmg.com/au/en/issuesandinsights/articlespublications/fraudsurvey/pages/fraud-survey-2010.aspx 
Levi, M. and Smith, R. (2011), "Fraud Vulnerabilities and the Global Financial Crisis", Trends and Issues in Crime and Criminal Justice, 422: pp. 1-6.

Markowitz, H. (1952), "Portfolio Selection", Journal of Finance, 7(1): pp. 77-91.

Mayhew, B. W. and Murphy, P. R. (2009), "The Impact of Ethics Education on Reporting Behaviour", Journal of Business Ethics, 86: pp. 397-416.

McManus Warnell, J. (2010), “An Undergraduate Business Ethics Curriculum: Learning and Moral Development Outcomes", Journal of Business Ethics Education, 7: pp. 63-84.

Michel, P. (2008), "Financial Crimes: The Constant Challenge of Seeking Effective Prevention Solutions", Journal of Financial Crime, 15(4): pp. 383-397.

Nguyen, N. T., Basuray, M. T., Smith, W. P., Kopka, D., and McCulloh, D. N. (2008), "Ethics Perception: Does Teaching Make a Difference?", Journal of Education for Business, Nov/Dec: pp. 66-75.

Norman, W. (2004), "Put an Ethicist on the Team! A Promising But Neglected 'Third Way' to Teach Ethics in a Business School”, Journal of Business Ethics Education, 1(2): pp. 257-274.

Office of Investigations (SEC) (2009), Investigation of the Failure of the SEC to Uncover Bernard Madoff's Ponzi Scheme. Available at: http://www.sec.gov/news/studies/2009/oig-509.pdf

Ramamoorti, S. (2008), "The Psychology and Sociology of Fraud: Integrating the Behavioral Sciences Component into Fraud and Forensic Accounting", Issues in Accounting Education, 23(4): pp. 521-533.

Securities and Exchange Commission (2011), SEC Enforcement Actions Addressing Misconduct That Led or Arose from the Financial Crisis. Available at: www.sec.gov/spotlight/enf-actionsfc.shtml, accessed 5/9/2011.

Sutherland, E. H. (1949), White-Collar Crime, New York: Dryden Press.

Swanson, D. L. and Fredrick, W. C. (2005), "Denial and Leadership in Business Ethics Education", in Ferrell, O. C. and Peterson, R. A. (Eds.), Business Ethics: The New Challenge for Business Schools and Corporate Leaders, New York: Sharpe.

Tomasic, R. (2011), "The Financial Crisis and the Haphazard Pursuit of Financial Crime", Journal of Financial Crime, 18(1): pp. 7-31.

US Department of Justice (2009), President Obama Establishes Interagency Financial Fraud Enforcement Task Force, Justice News Press Release (November 17). Available at: http:// www.justice.gov/opa/pr/2009/November/09-opa-1243.html

Walker, P. (2009), "Who Taught Them Greed Is Good? To What Extent Are Business Schools' MBA Courses Responsible for the Global Financial Crash?", The Observer (March 8). Available at: http://www.guardian.co.uk/business/2009/mar/08/credit-crunch-mbas 